\title{
A VERSÃO WWW DA REVISTA DA ASSOCIAÇÃO MÉDICA BRASILEIRA (RAMB)
}

Médicos, pesquisadores, clínicos e cirurgiões têm se dedicado - ao longo dos anos-a gerar novos conhecimentos fisiológicos e fisiopatológicos, desenvolver novos medicamentos, criar e aperfeiçoar instrumentos, e a aprimorar técnicas para aplicação na prática da medicina objetivando agregar benefícios aos pacientes. $O$ ensino da medicina envolve organizar e difundir todo 0 conhecimento gerado pela pesquisa $\mathrm{e}$ pelaexperiência prática doseducadores. A quantidade de informação produzida é tão grande que seria impossivel uma atualização adequada individualmente.

Nos últimos anos, os médicos em geral têm se acostumado a utilizar os computadores como ferramenta de ajuda no seu aprimoramento científicoe no ensino. $A$ internet é sem dúvida nenhuma o instrumento que mais longe e mais rápido movimenta informação, de forma fácil e compartilhada, modificando definitivamente $\mathrm{o}$ conceito de inteligência de um estático "Saber informações", para um mais dinâmico "Pesquisar e relacionar informações". Este veículo permite filtrar a informação relevante para um aprendizado orientado por demanda - pesquisamos e aprendemos "o quê" e "quando" precisamos.
A Revista da Associação Médica Brasileira, através do seu corpo editorial, tem se empenhado na melhoria constante desta publicação, preocupando-se com a seleção de um conteúdo científico relevante, com o objetivo de divulgar a pesquisa original e também oferecer material didático de qualidade aos leitores, através de suas diversas seções. A Ramb tornou-se um importante meio de divulgação científica em Medicina na nossa comunidade, já reconhecida pelos pesquisadores e pelas instituições de fomento à pesquisa. Este reconhecimento reflete-se em um crescente número de artigos científicos de qualidade produzidos por pesquisadores e enviados para publicação.

O substancial aumento de artigos submetidos à avaliação pelo corpo editorial da Ramb desencadeou a necessidade de adaptar o modelo de fluxo clássico de análise dos manuscritos, para um modelo mais rápido e eficiente que conseguisse manter comunicação contínua entre os autores, editores e revisores.

Nesse sentido, o desenvolvimento de uma versão eletrônica da Ramb, utilizando a internet como veículo de comunicação, teve como objetivo disponibilizar aos colegas da área da saúde, aos pesquisadores, aos potenciais autores e ao corpo editorial uma ferramenta de melhoria da eficiência da revista, para continuar oferecendo aos médicos de nossa comunidade científica um excelente e dinâmico meio de divulgação e consulta.

A revista eletrônica, em breve, estará disponível aos colegas como um complemento à revista impressa - para servir de interface entre nós; desde a simples consulta de artigos publicados, ao envio de manuscritos, além de todo o fluxo de análise até a publicação do artigo, quando aprovado, sempre com o acompanhamento contínuo dos autores e do corpo editorial.

Desta forma, estaremos contribuindo para organizar e divulgar 0 conhecimento médico de uma maneira rápida e dinâmica, como a que acreditamos ser a adequada para o pesquisador e o leitor de hoje.

Aos senhores assinantes e colaboradores, desejamos o proveito pleno desse importante e irreversível passo que a RAMB dá para a sua consolidação entre as maiores revistas científicas brasileiras. 